\title{
ТРАНСГЕНЕРАЦИСКА ВИКТИМИЗАЦИЈА И ТРАНСГЕНЕРАЦИСКА ВИКТИМНОСТ: ДЕФИНИЦИИ, НАЧИНИ НА ПРЕНЕСУВАЊЕ И ПОСЛЕДИЦИ
}

\section{Маја Симоновска ${ }^{1}$}

\section{Кратка содржина}

Пренесувањето на траумата од генерација на генерација претставува феномен за кој сѐ повеќе се зборува во литературата. Постојат повеќе концепти во литературата со кои се прават обиди да се објасни овој феномен. Специфичноста на трансгенерациската виктимизација се огледува во тоа што траумата се пренесува на потомци кои директно не биле изложени на трауматскиот настан, а ефектите не се пројавуваат само на индивидуално, туку и на групно ниво. Научните истражувања сѐ уште се во зародиш поради комплексноста на овој феномен и досега главно се од квалитативна природа. Целта на овој труд е да даде основен осврт на концептите на трансгенерациската виктимизација и трансгенерациската виктимност, начинот на пренесување и последиците од нив.

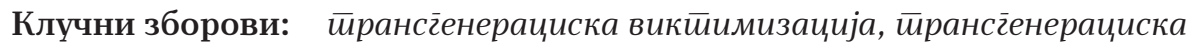

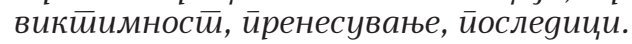

majasim@gmail.com 
М. СИМОНОВСКА: ТРАНСГЕНЕРАЦИСКА ВИКТИМИЗАЦИЈА И ТРАНСГЕНЕРАЦИСКА ВИКТИМОСТ...

\section{Вовед}

Постојаната виктимизација, односно процесот на пренесување на траумата од една генерација на друга е сѐ почесто присутна во истражувањата од областа на социјалната психологија. Станува збор за траума која била доживеана од страна на цела група (помала или поголема), а последиците од неа се присутни и препознатливи и неколку генерации подоцна.

Во одредени случаи траумата доживеана од страна на едно лице може да се пренесе на неговите/нејзините потомци. Во таквите случаи кај потомците се среќаваат слични или исти начини на однесување како кај лицето кое ја доживеало траумата. Односно, пренесената траума влијае на менталното здравје на потомците и на начинот на кој тие се справуваат со секојдневните предизвици. Во зависност од причинителот и од социјалниот контекст, некои трауматски искуства се пренесуваат само во рамките на семејството, додека пак одредени видови траума влијаат на големи групи или општества.

Изучувањето и давањето соодветно значење на овој феномен е од исклучителна важност поради тоа што речиси во сите земји на светот постоеле војни и трауми кои се пренесуваат од генерација на генерација и кои влијаат врз начинот на кој потомците се однесуваат, се справуваат со предизвиците од нивното време, но и на начинот на кој го перципираат светот.

Во рамките на стручната литература постојат неколку термини со кои се прават обиди да се опише овој феномен. Во дел од дефинициите постои преклопување, а кај дел постојат специфики врзани за одредена целна група која била истражувана. Целта на овој труд е да даде основен осврт на концептот на трансгенерациска виктимизација и трансгенерациска виктимност, начинот на кој се пренесува и нејзините ефекти врз потомците.

\section{Трансгенерациска траума}

Трансгенерациската траума претставува траума која се пренесува од генерација на генерација, а содржи елементи на индивидуална траума и колективна траума. Во случаи кога трауматските настани биле од поголеми размери како на пример војни, несреќи и слично, трауматските доживувања, кои се јавиле како последица од нив, може да се пренесат на следните генерации во форма на колективна траума. Колективните трауми може да се пренесуваат на неколку генерации на потомци, не само во рамките на семејството туку и на групно ниво. Потомците на оние кои биле трауматизирани, а притоа самите не биле изложени на трауматскиот настан/и, немаат сеќавање на истиот, а во одредени случаи немаат ни сознанија дека такви настани се случиле, може 
да пројават однесувања и чувства кои се исти или слични со оние на нивните трауматизирани предци (Taylor et al., 2020; König \& Reimann, 2018).

Ваквиот вид траума настанува бидејќи лицата или групите не успеале соодветно да ги асимилираат преживеаните трауми. Односно, индивидуите кои биле изложени на трауматски настан/и, ги пренесуваат траумите на следните генерации доколку немаат доволно механизми или пак немаат соодветни механизми да се справат со нив. Поради тоа, ги пренесуваат траумите на своите потомци кај кои се среќаваат чувства на гнев, страв, вина, чувство на одговорност и физички реакции, односно симптоми кои се споредливи со оние кои се јавуваат при индивидуалната трауматизација (König \& Reimann, 2018; Buonagurio, 2020).

Траумите се пренесуваат од генерација на генерација преку колективни наративи, емоции, вредности и норми и стануваат семејна меморија (Кӧnig \& Reimann, 2018). Во процесот на пренесување, трауматското искуство добива елементи од минатото и сегашноста (Mohatt et al., 2014). Пренесувањето исто така се одвива и преку училиштето и медиумите (Taylor et al., 2020).

DSM V препознава дека траумата може да биде пренесена во рамките на повеќе генерации. Притоа во рамките на критериумите за посттрауматското стресно растројство стои и дека тоа може да се јави како резултат на дознавање за трауматско искуство кое му се случило на член на семејството или близок пријател, при што настанот или настаните може да биле случајни или резултат на насилство (АРА, 2013).

Во литературата се среќаваат два термина поврзани со пренесувањето на траумата на групно ниво: колективна виктимизација (collective victimization) и колективна виктимност (collective victimhood). Додека колективната виктимизација се однесува на штетата нанесена на групата од страна на друга група како ропство, етнички конфликт, геноцид и слично, колективната виктимност се однесува на искуствата и на психолошките последици од нанесената штета. Колективната виктимност може да се појави како резултат од колективна виктимизација, но сите случаи на колективна виктимизација не придонесуваат за појава на колективна виктимност (Noor et al., 2017). Терминот колективна виктимизација се однесува на траума која влијаела на групите, но нејзината појава не означува дека таа ќе влијае на следните генерации (Mohatt et al., 2014).

\section{Концепти на трансгенерациска виктимизација}

Постојат повеќе концепти со кои се опишува пренесувањето на траумите низ генерации на потомци, односно за процесот на трансгенерациска викти- 
М. СИМОНОВСКА: ТРАНСГЕНЕРАЦИСКА ВИКТИМИЗАЦИЈА И ТРАНСГЕНЕРАЦИСКА ВИКТИМОСТ...

мизација (transgenerational victimization). Иако Буонагурио (Buonagurio, 2020) наведува дека концептот на трансгенерациска виктимизација може да се сретне под називите трансгенерациска траума, интергенерациска траума, културна траума и историска траума, во рамките на нивните дефиниции постојат разлики. Во сите случаи станува збор за траума која била доживеана од минатите генерации, а сѐ уште предизвикува трауматски одговори кај потомците, без притоа тие да ја искусиле иницијалната траума.

Терминот историска траума (historical trauma) се однесува на траума која се доживува низ повеќе генерации од страна на една група која има заеднички идентитет, заеднички контекст во кој постои, а нејзините членови имаат чувства на припадност кон групата. Историската траума се состои од три примарни елементи: трауматски настан, споделување на траумата меѓу група на лица и споделување на траумата во повеќе генерации (Mohatt et al., 2014). Споделувањето на траумата низ генерациите има поголема веројатност да се случи доколку постои силна идентификација на потомците со сопствената група (Evans-Campbell, 2008).

Интергенерациска траума (intergenerational trauma) е концепт со кој се опишува траума која се пренесува од генерација во генерација. Но, овој термин не укажува дека траумата се пренесува на групно ниво. Односно, траумата може да се пренесува само во рамките на едно семејство (Mohatt et al., 2014). Негативните последици од пренесувањето на интергенерациската траума опфаќаат опсег на психијатриски симптоми и зголемена подложност на стрес (Sangalang \& Vang, 2017).

Стам со соработниците (Stamm et al., 2004) и Барден (Barden, 2013) зборуваат за културолошка траума (cultural trauma). Изложувањето на една група која има своја култура на друга група која носи друга култура може да доведе до појава на културолошка траума која се јавува како резултат на колонизација, миграции, војни, окупации и слично. Иако трауматските настани и загуби имаат универзални компоненти, начинот на реакција и одговор на нив се разликува во рамките на различните културни контексти. Како резултат на тоа во одредени култури симптомите не се исти со оние наведени во описот на посттрауматското стресно растројство (PTSD). Затоа, овие автори нагласуваат дека треба да се прилагоди начинот на кој се дефинираат траумите. Со тоа би можеле да се создадат интервенции кои се во согласност со актуелните потреби на групата.

Волкан (Volkan, 2001) го воведува концептот на избрана траума (chosen trauma). Според него, кога една група ќе доживее трауматски настан, иако поголемиот дел од нејзините членови одбираат да не се чувствуваат виктимизирано или понижено, одреден дел од нив несвесно „избираат“ на својот 
идентитет да додадат ментална репрезентација на траума од нивните предци. Избраната траума е поврзана со неспособноста на претходните генерации да ги обжалат загубите од трауматски настан. Нарушената слика за себеси заедно со менталните репрезентации на споделениот трауматски настан се вгнездуваат во следните генерации кои треба да ги обжалат настаните од минатото, да се изборат со понижувањето или да го надминат. Доколку потомците од втората генерација не успеат да се справат со обжалувањето или понижувањето доживеано поради траумата, тогаш таа се пренесува на следната генерација. Избраната траума ја менува својата функција со преминувањето од генерација во генерација, станува дел од идентитетот на групата и ги поврзува нејзините членови. Таа претставува моќна психолошка сила и може да биде употребена од страна на лидерите кога групата се соочува со големи промени, се наоѓа во конфликт или пак потребно е да се засили нејзиното чувство на идентитет.

Одредени автори работејќи со одредени групи го препознаваат феноменот на пренесување на траумата низ генерации и му даваат назив во согласност со карактеристиките на групата која ја истражувале. Дуран (Duran, 2006) истражувајќи ги американските Индијанци и пренесувањето на траумите во рамките на нивните семејства, зборува за „душевна рана“ (soul wound). Тој го нагласува значењето на холистичкиот пристап и предлага начини за надминување на траумите кои се засноваат на хармонијата меѓу телото, умот и духот, што е во согласност во верувањата и пристапот на американските Индијанци.

Леари Дегриј (Leary Degruy, 2005), која ги истражувала Афроамериканците го воведува терминот посттрауматски синдром на ропство (Post Traumatic Slavery Syndrome). Таа зборува за пренесувањето на траумите низ генерации и ефектите кои тие трауми ги имаат до денешниот ден, како лошо ментално и физичко здравје, дисфункционални семејни релации и самоуништувачко однесување. Укажува дека единствен начин на кој лечењето на групата може да започне е преку уважување на отпорноста на Афроамериканците, а не чекањето доминантната култура да преземе акции против расизмот.

\section{Концепти на трансгенерациска виктимност}

Во литературата се среќаваат концепти кои се однесуваат конкретно на виктимноста. Трансгенерациска виктимност (transgenerational victimhood) го претставува начинот на кој колективната виктимност се пренесува на следните генерации. Со концептот на колективна виктимност се опишуваат и истражуваат наративните, училиштето и медиумите преку кои пораките се пренесуваат и начините на кои потомците ги примаат и толкуваат информа- 
М. СИМОНОВСКА: ТРАНСГЕНЕРАЦИСКА ВИКТИМИЗАЦИЈА И ТРАНСГЕНЕРАЦИСКА ВИКТИМОСТ...

циите. Исто така и на начинот на кој овие информации влијаат на ментално здравје на потомците (Taylor et al., 2020).

Концептот на инклузивна виктимност (inclusive victimhood, inclusive victim consciousness, common victimhood) вклучува препознавање дека другата група страдала на слични начини како и сопствената група. Истражувањата покажуваат дела лицата кои имаат висока инклузивна виктимност покажуваат помала тенденција за компетитивна виктимност, подготвеност за простување на другата група, солидарност и поддршка на другите (Noor et al., 2017).

Под ексклузивна виктимност (exclusive victimhood или exclusive victim consciousness) се подразбира верувањето на членовите на групата дека нивното страдање е единствено и различно од страдањето на другите групи. Во рамките на овој термин се вклучени и концептите за компетитивна виктимност и НПВВ. Ексклузивната виктимност може да биде предизвикана од страна на членовите на групата или лидерите со цел да се добијат материјални и психолошки придобивки или предности за сопствената група (Vollhardt \& Bilali, 2014).

Насоченост кон постојана внатрегрупна виктимност - НПВВ (Perpetual in-group victimhood orientation - PIVO) претставува концепт кој е поврзан со трансгенерациската виктимизација, затоа што предуслов за нејзината појава е групна траума која се случила во минатото и се пренесува од генерација на генерација. Дополнително, во рамките на групата постои верување дека нејзините членови се жртви низ вековите, а нивната група е под постојана закана. Односно, по иницијалната траума која се јавила во минатото, низ годините и вековите членовите на групата продолжиле да бидат трауматизирани токму поради припадноста во истата. Овој концепт е специфичен поради тоа што ги поврзува непријателите, перципираните неправди и перципираната закана од минатото со оние од сегашноста, со што постои перцепција кај членовите на групата дека заканата за групата е постојана (Schori-Eyal et al., 2017b; SchoriEyal et al., 2017a).

Интергрупната компетитивна виктимност (intergroup competitive victimhood) претставува концепт во кој виктимноста се опишува како психолошки ресурс во однос на кој постои натпревар меѓу групите кои биле или се во актуелен конфликт. Натпреварот меѓу групите се јавува без разлика на улогата на која било од групите во рамките на конфликтот. Притоа, целта на секоја од групите е да ја прикаже својата група како група која страдала повеќе од другата. Натпреварот меѓу групите може да се јави во однос на различни димензии на колективната виктимизација, како на пример физичката димензија (која група имала повеќе жртви во конфликтот или страдала повеќе), материјалната димензија (која група изгубила повеќе ресурси), културолошката димензија 
(која група во поголема мера била присилена да се откаже од својот начин на живот), психолошката димензија (која група имала поголеми проблеми со психолошката добросостојба) и моралната димензија (која група навистина е жртва) (Noor et al., 2017; Demirel \& Eriksson, 2019; Young \& Sullivan, 2016).

Стравот да се виктимизира (fear of victimizing - FOV) претставува начин на размислување, загриженост дека сопствената група ќе стане агресор без да ги почитува моралните стандарди и ќе ги повреди другите групи. Се смета дека стравот да се виктимизира потекнува од траума која ѝ била нанесена на групата во минатото, а истата опстојува до денешниот ден. Во овој случај групата се грижи дека ќе ја промени својата улога на жртва и ќе стане агресор. Стравот да се виктимизира е поврзан со тенденцијата да се избегне претераното насилство или да се направат неморални дејства кон непријателите на сопствената група, повисоки нивоа на вина во рамките на групата, помала толеранција на колатерални жртви кај непријателот и поголема подготвеност за простување и помирување (Schori-Eyal et al., 2017b; Schori-Eyal et al., 2017a).

\section{Пренесување на траумите од генерација на генерација}

Иако различни семејства може да доживеат иста несреќа, можно е траумата да се појави само кај дел од тие семејства. Тоа укажува дека пренесувањето на траумата не е праволиниско, а поради тоа нејзиното емпириско испитување и докажување е поспецифично (Buonagurio, 2020).

Кизилан и Вензел (Kizilhan \& Wenzel, 2020), опишуваат три фази во кои трауматскиот настан станува трансгенерациски. Во рамките на првата фаза, групата ја доживува траумата, во втората фаза се појавува реакција на траумата, а во третата фаза траумата се пренесува на следните генерации. Во рамките на првата генерација меѓу останатите може да се појават симптоми на посттрауматско стресно растројство (PTSD), знаци на депресија, а исто така честа е појавата на страв, вина, жалење кои понатаму може да придонесат до појава на физички заболувања. Сето горенаведено влијае на однесувањето, емоциите и когницијата на преживеаните кои преку наративи/приказни, религиски церемонии, музика и слично ги пренесуваат своите доживувања. Со ваквото пренесување се обликува колективната меморија и се влијае на засилување на траумата преку процесот на интеракција.

Бар-Он и Розентал (Bar-On, 1989; Rosenthal, 1999) во своите книги наведуваат шеми според кои може да се одвива пренесувањето на трансгенерациската траума. Една од шемите се однесува на избегнувањето и молчењето како начини на справување со трауматскот настан. Првата генерација, која ја доживеала 
М. СИМОНОВСКА: ТРАНСГЕНЕРАЦИСКА ВИКТИМИЗАЦИЈА И ТРАНСГЕНЕРАЦИСКА ВИКТИМОСТ...

траумата, избегнува да зборува за траумата и да се соочи со неа, следната, втора генерација го научува избегнувањето и молчењето поврзано со траумата од своите родители. Исто така кај индивидуите од втората генерација се јавува потреба да бидат лојални и „добри деца“ на своите родители. Доколку и втората генерација преживее траума тогаш третата генерација ќе ги пројави истите однесувања односно избегнување, молчење, срам и/или чувство на вина.

Оваа шема ја препознава и Келерман (Kellermann, 2001) кој го истражувал родителскиот стил кај втората генерација преживеани на холокаустот. Според него родителите кои го преживеале холокаустот се разликувале од останатите родители само во однос на промената на улогите родител - дете каде детето поради грижа за родителот ја презема „родителската функција“. Истиот наод се потврдува и во истражувањето на Даниели со соработниците (Danieli et al., 2015) и истражувањето на мајките од Руанда спроведено од страна на Беркмос со соработниците (Berckmoes et al., 2017).

За одредени нарушувања во компетенциите за родителство кои придонесуваат за пренесување на трансгенерациската траума зборуваат и други автори (Spinazzola et al. 2005; Kizilhan \& Wenzel, 2020). Родителите кои се трауматизирани ја пренесуваат траумата поради нивната намалена емотивна врзаност која придонесува тие да не се способни да создадат соодветно поврзување со своето дете. Со тоа иницијалната релација меѓу родителот и бебето носи траума, која продолжува за време на детството.

Постојаното прераскажување на преживеаните настани, исто така претставува шема која ја препознаваат Бар-Он и Розентал (Bar-On, 1989; Rosenthal, 1999). Со постојаното прераскажување се пренесуваат доживеаните чувства и симболите на следните генерации. Односно тоа придонесува траумите да се пренесат на следните генерации. Кренан и Бароус (Kreenan \& Burrows, 2012) ja препознаваат истата шема работејќи со лица од С Ирска. Според нив постојаното прераскажување на трауматските настани не придонесува за интегрирање на трауматското искуство. Наместо тоа, доведува до уште поголемо фиксирање на настанот и трауматизирање на потомците на оние кои ја доживеале траумата. За да се надмине траумата авторите посочуваат дека е значајно да се согледа значењето кое настанот го има за лицата.

Бар-Он и Розентал (Bar-On, 1989; Rosenthal, 1999) како шема ја препознаваат и тивката и спора промена на социјалните норми кои водат до намалување на традиционалните социјални релации во семејствата која може да доведе и до зголемена злоупотреба на супстанци и појава на физичко и семејно насилство. За оваа шема зборуваат и Кизилхан и Вензел (Kizilhan \& Wenzel, 2020), кои наведуваат дека трауматизираната прва генерација може да пројави различни 
девијантни однесувања и социјални проблеми кои понатаму ја трауматизираат следната генерација, тие преку учење преку модел ги учат овие видови несоодветни однесувања, со тоа шемите на однесување се пренесуваат на

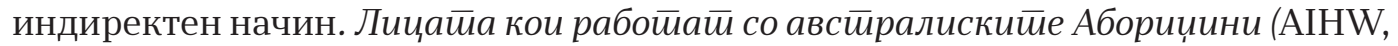
2018), американските Индијанци (Brave Heart Yellow Horse, 2013; Duran, 2006) исто така укажуваат на појавата на девијантни појави и социјални проблеми со кои се соочуваат трауматизираните заедници.

Пренесувањето на одговорноста и вината на следните генерации или пренесување на одговорноста на „лидерите“ и избегнување вина исто така претставува шема за која зборуваат Бар-Он и Розентал (Bar-On, 1989; Rosenthal, 1999).

Дополнително, социјалниот контекст во кој живеат потомците на лицата кои биле трауматизирани, исто така може да влијае на доживувањето на трауматското искуство како на пример социјалната нееднаквост, сиромаштијата, неправдата или дискриминацијата. Личното негативно искуство на потомците им го потврдува она што го научиле од нивните предци. Со тоа траумата опстојува и се пренесува на следните генерации (Kizilhan \& Wenzel, 2020).

\section{Истражувања за пренос на траумите низ генерации}

Постојат голем број истражувања насочени кон трауматските искуства на поединци, но многу малку кои се однесуваат на трауматските искуства кои се пренесуваат на следните генерации (Vollhardt, 2012). Најраните истражувања за пренесувањето на траумите низ генерациите потекнуваат од 60-тите години на минатиот век, и се однесуваат на трауматските искуства на потомците на оние кои го преживеале холокаустот (DeAngelis, 2019). Комплексноста на процесот на пренос на траумата и несоодветните истражувачки нацрти придонеле оваа тема да се гледа како контроверзна (Kizilhan \& Wenzel, 2020).

Повеќето истражувања се теоретски и квалитативни, а потребни се квантитативни истражувања кои ќе придонесат подобро да се разбере овој феномен. Исто така, треба да се земе предвид целиот процес и социјалниот контекст во кој потомците живеат (Kellerman, 2001; Sagi-Schwartz et al., 2008).

Денес има повеќе отворени прашања кои се поврзани со проучувањето на трансгенерациската виктимизација и виктимност, а се однесуваат на втората или на третата генерација потомци. Тие вклучуваат: дали навистина постои индиректно влијание врз потомците, дали има карактеристични универзални синдроми, каква е преваленцијата на ментални и здравствени проблеми, дали потомците имаат подобра резилиентност за одредени животни предизвици, 
М. СИМОНОВСКА: ТРАНСГЕНЕРАЦИСКА ВИКТИМИЗАЦИЈА И ТРАНСГЕНЕРАЦИСКА ВИКТИМОСТ...

кои механизми од горенаведените може да се интегрираат за да се креира т.н. „Универзален модел“? (Kizilhan \& Wenzel, 2020).

Истражувањата спроведени на Палестинци (Palosaaria et al., 2013), Курди (Kizilhan \& Wenzel, 2020), Украинци (Bezo \& Maggi, 2015), американски и канадски Индијанци (Bombay et al., 2014; Brave Heart Yellow Horse, 2013; Evans-Campbell, 2008; Duran, 2006) итн., покажуваат дека кај потомците се јавуваат различни симптоми на посттрауматско стресно растројство или реакции на траума. Тие симптоми вклучуваат деперсонализација, амнезија, кошмари, хипервигилност, злоупотреба на супстанци, чувства на вина и жал, итн.

Дахорст со соработниците (Dashorst et al., 2019) идентификувале 23 истражувања кои биле спроведени во периодот од 2000 до 2018 година, а се однесувале на лицата кои го преживеале холокаустот. Наодите укажуваат дека потомците на лицата кои биле жртви на холокаустот се поранливи на стрес, но само кога се соочени со реална закана. Оние на кои двајцата родители го преживеале холокаустот имале повеќе проблеми со менталното здравје во споредба со оние кои имале само еден родител кој го преживеал холокаустот. Пронајдена е поголема преваленца на психијатриски симптоми кај потомците, која е поврзана со менталните проблеми на родителите особено во врска со нарушувања на расположението, анксиозни нарушувања и злоупотреба на супстанци. Посттрауматското стресно растројство кај родителите било поврзано со посттрауматско стресно растројство и депресивни симптоми кај децата. Исто така истражувањата укажуваат на промени во метаболизмот на кортизол кај потомците што може да предизвика несоодветна реакција на стрес, зголемена ранливост на стрес, но во зависност од нивоата на кортизол исто така може да придонесе и за појава на зголемена отпорност на стрес.

Даниели со соработниците (Danieli et al., 2015) создале прашалник за ефектите од холокаустот врз потомците на оние кои го преживеале. Истражувањето спроведено користејќи го прашалникот како инструмент открило дека потомците покажуваат несигурност во нивните компетенции, имаат потреба да ги заштитат своите родители, биле отуѓени од нивните врсници, опседнати со холокаустот, имале потреба постојано да имаат контрола и покажувале незрела зависност.

Истражувања на домородните Американци и Канаѓани откриваат слични наоди кај нивните потомци. Во САД постоела одлука во периодот од 1880 до 1990 година според која децата на Индијанците биле одвојувани од нивните родители и носени во интернати со цел да се елиминира т.н. „индијански проблем“. Децата чии родители биле дел од овие училишта како и нивните внуци покажувале знаци на стрес, проблеми со учењето, депресивни симптоми, 
проблеми на училиште, поголема веројатност на обиди за самоубиство и поголема појава на хепатитис Ц поради злоупотреба на дроги (Bombay et al., 2014).

Истражувањата на „украдените генерации“ на Абориџините и нивните потомци посочуваат слични ефекти, односно хронични здравствени, социјални и економски проблеми. Понатаму, појава на симптоми на дисоцијација, алкохолизам, депресија, беспомошност, девалвација на сопствената култура и себеси, тага, срам, вина, неспособност да веруваат на другите. Овие симптоми се присутни кај потомци, седум генерации откако нивните предци ја доживеале иницијалната траума. Оние кои насила биле земени од нивните семејства во поголем процент добиваат затворски казни, позависни се од финансиски средства од владините институции и имаат лошо физичко и ментално здравје. (AIHW, 2018).

Безо и Маги (Bezo \& Maggi, 2015) истражувале три генерации во рамките на 15 украински семејства во однос на геноцидот во Холодомор, Украина. Тие откриле дека тој настан влијаел на третата генерација на потомци. Наодите добиени од полуструктурирани длабински интервјуа откриле дека емоциите како на пример (страв, недоверба, тага, стрес, вознемиреност, намалено чувство за сопствената вредност и индиферентност кон другите) и стратегиите за справување (давање посебен фокус на храната, чување храна и пренатрупување со храна, прејадување, неможност да се фрлат непотребни работи, вклучување во активности ризични по здравјето) кои ги користеле нивните баби и дедовци за да преживеат биле пренесени на нивните потомци.

Беркмос со соработниците (Berckmoes et al., 2017) интервјуирале мајки кои го преживеале геноцидот во Руанда и нивните деца. Откриле дека мајките не ги споделувале своите искуства со децата и се надевале дека такви настани нема да се случат во иднина. Исто така ја истражувале втората генерација потомци на жртвите од геноцидот и откриле слабо родителствување, додека пак тинејџерите покажувале обиди да им помогнат на родителите колку што е можно повеќе.

\section{Заклучок}

Проучувањето на колективната и трансгенерациската траума открива нови аспекти на процесите на трауматизација кои се однесуваат на ефектите кои траумите може да ги имаат врз групите. Наодите од истражувањата сѐ појасно откриваат дека на општествата влијаат и колективната и индивидуалната траума. Нивната појава не зборува само за ранливоста на семејствата и групите, туку и на општествата како целина. А долготрајноста и сериозноста на симптомите кои се јавуваат неколку генерации по иницијалната траума укажуваат 
М. СИМОНОВСКА: ТРАНСГЕНЕРАЦИСКА ВИКТИМИЗАЦИЈА И ТРАНСГЕНЕРАЦИСКА ВИКТИМОСТ...

на важноста за нивно проучување и пронаоѓње начини за да се помогне во подобрувањето на менталното здравје на овие индивидуи и групи.

Сознанијата за феноменот на трансгенерациска виктимност не се нови, но сѐ уште не постои единствен термин и единствена дефиниција која ги обединува сите досегашни сознанија. Така што денес се среќаваме со различни термини кои во најголема мера објаснуваат ист феномен, иако постојат и разлики меѓу нив. Нур со соработниците (Noor et al., 2017), укажуваат дека постои разлика во термините виктимизација и виктимност. Но, во рамките на дефинициите и описите на различни автори сѐ уште се јавува мешање на значењето на овие два термина. Па како резултат на тоа под називот виктимизација често стојат описи и за нејзините ефекти.

Понатаму, преку истражувањата откриено е дека некои од групите кои се виктимизирани покажуваат тенденција да поддржуваат агресивни мерки кон другите групи и ги оправдуваат неморалните дејства кон нив, додека пак други групи се насочени кон простување. Оние лица кај кои НПВВ е висока покажуваат тенденција да поддржуваат агресивни мерки кон другите групи кои се перципирани како непријатели, да имаат пониско ниво на вина, морална одговорност, емпатија, простување и помирување, помала подготвеност да се признаат штетите направени од сопствената група, поддршка и агресија кон непријателските групи. (Schori-Eyal et al., 2017b; Schori-Eyal et al., 2017a). За разлика од нив лицата со висока инклузивна виктимност како и лицата со висок страв од виктимизација покажуваат тенденција на простување и поддршка на другите групи, избегнување неморални дејства, повисоки нивоа на чувство на вина во рамките на групата и помала толеранција кон жртви во групите кои се сметаат за непријателски (Noor et al., 2017).

Она за коешто се согласни дел од авторите е дека треба да се уважи специфичноста на групата, нејзината историја и верувања (Duran, 2006; Brave Heart Yellow Horse, 2013; AIHW, 2018; Kreenan \& Burrows, 2012). Односно да се увиди кои се потребите на групата, и врз основа на нив да се создадат соодветни интервенции. Треба да се има предвид дека авторите кои ова го потенцираат, своите заклучоци ги црпат од директната работа со групите на подобрување на нивното ментално здравје. Од друга страна истражувањата за колективната виктимност се фокусираат главно на искуствата на поединци и на нивната перцепција за виктимизација, наместо на колективните процеси (Noor et al., 2017), што укажува на потребата да се земат предвид сите искуства и знаења од различни дисциплини кои работат на подобрување на менталното здравје на групи кои се соочуваат со трансгенерациска виктимност. 
ПСИХОЛОГИЈА: НАУКА И ПРАКТИКА, VOL. IV

Потребни се и дополнителни истражувања со кои ќе се објасни зошто се пренесува траумата од генерација на генерација, како таа се пренесува низ неколку генерации и на кој начин може да се интервенира за да се надминат трауматските искуства кај различните генерации. Потребно е наодите од тие истражувања да се поврзат со спектарот на трауматски нарушувања и да се предложат конкретни интервенции што би значело дополнување во DSM во однос на симптомите, реакциите и препознавањето на овој вид траума. 
М. СИМОНОВСКА: ТРАНСГЕНЕРАЦИСКА ВИКТИМИЗАЦИЈА И ТРАНСГЕНЕРАЦИСКА ВИКТИМОСТ...

\section{Литература}

American Psychiatric Association (APA). (2013). Diagnostic and statistical manual of mental disorders (5th ed.). American Psychiatric Association Publishing. https://doi.org/10.1176/appi.books.9780890425596.

Australian Institute of Health and Welfare (AIHW). (2018, Aug 15). Aboriginal and Torres Strait Islander Stolen Generations and descendants: numbers, demographic characteristics and selected outcomes. https://www.aihw. gov.au/reports/indigenous-australians/stolen-generations-descendants/ contents/table-of-contents.

Barden, K. P. (2013). Remembering the Cultural Trauma Legacies of Slavery: African American Young Adult Perceptions on Racism, Ethnic Identity, and Racial Socialization (660) [Doctoral dissertation, Loyola University Chicago]. Dissertations. http://ecommons.luc.edu/luc_diss/660.

Bar-On, D. (1989). Legacy of Silence: Encounters with Children of the Third Reich. Harvard University Press.

Berckmoes, L. H., Eichelsheim, V., Rutayisire, T., Richters, A., \& Hola, B. (2017). How Legacies of Genocide are Transmitted in the Family Environment: A Qualitative Study of Two Generations in Rwanda. Societies, 7(3), 24. https:// doi.org/10.3390/soc7030024.

Bezo, B., \& Maggi, S. (2015). Living in "survival mode:" Intergenerational transmission of trauma from the Holodomor genocide of 1932-1933 in Ukraine. Social Science \& Medicine, 134, 87-94. https://www.sciencedirect. com/science/article/abs/pii/S0277953615002294?via\%3Dihub

Bombay, A., Matheson, K., \& Anisman, H. (2014). The intergenerational effects of Indian Residential Schools: Implications for the concept of historical trauma. Transcultural Psychiatry, 51(3), 320-338. doi: 10.1177/1363461513503380.

Brave Heart Yellow Horse, M. (2013). Historical Trauma and Parenting [PowerPoint Slides], Indian Health Service, The Federal Health Program for American Indians and Alaska Natives. https://www.ihs.gov/sites/ telebehavioral/themes/responsive2017/display_objects/documents/slides/ historicaltrauma/htparenting0613.pdf

Buonagurio, N. (2020). The Cycle Continues: The Effects of Intergenerational Trauma on the Sense of Self and the Healing Opportunities of Dance (280) [Doctoral dissertation, Lesley University]. Expressive Therapies Capstone Theses. https://digitalcommons.lesley.edu/expressive_theses/280.

Danieli, Y., Norris, F. N., Lindert, J., Paisner, V., Kronenberg, S., Engdahl, \& B., Richter, J. (2015). The Danieli Inventory of Multigenerational Legacies of 
Trauma, Part II: Reparative Adaptational Impacts. American Journal of Orthopsychiatry, 85(3), 229-237. DOI: 10.1037/ort0000055.

Dashorst, P., Mooren, T. M., Kleber, R. J., de Jong, P. J., \& Huntjens R.

J. C. (2019). Intergenerational consequences of the Holocaust on offspring mental health: a systematic review of associated factors and mechanisms. European Journal of Psychotraumatology, 10(1). doi: 10.1080/20008198.2019.1654065.

DeAngelis, T. (2019). The legacy of trauma, An emerging line of research is exploring how historical and cultural traumas affect survivors' children for generations to come. American Psychological Association. https://www. apa.org/monitor/2019/02/legacy-trauma.

Demirel, C., \& Eriksson, J. (2019). Competitive victimhood and reconciliation: the case of Turkish-Armenian relations. Identities, 27(5), 537-556. DOI: 10.1080/1070289X.2019.1611073.

Duran, E. (2006). Healing the Soul Wound: Counseling with American Indians and Other Native Peoples, Multicultural Foundations of Psychology and Counseling Series. Teachers College Press.

Evans-Campbell, T. (2008). Historical trauma in American Indian/Native Alaska communities: A multilevel framework for exploring impacts on individuals, families, and communities. Journal of Interpersonal Violence, 23(3), 316-338. DOI: 10.1177/0886260507312290.

Kellermann, N. (2001). Perceived parental rearing behavior in children of Holocaust survivors. The Israel journal of psychiatry and related sciences, 38, 58-68. https://www.researchgate.net/publication/11956569_Perceived_parental_ rearing_behavior_in_children_of_Holocaust_survivors.

Kizilhan, J., \& Wenzel, T. (2020). Concepts of Transgenerational and Genocidal Trauma and the Survivors of ISIS Terror in Yazidi Communities and Treatment Possibilities. International Journal of Mental Health and Psychiatry, 6 (1), doi: 10.37532/ijmhp.2020.6(1).174.

König, U., \& Reimann, C. (2018). Closing a gap in conflict transformation: Understanding collective and transgenerational trauma. XImpulse. https:// www.ximpulse.ch/wp-content/uploads/1806CollectiveTrauma.pdf.

Kreenan, B., \& Burrows, R. (2012). Extraordinary skills in extraordinary circumstances: supporting parents, children, and caregivers in the transition from armed conflict in the North of Ireland. In E. C. Nevis \& J. Melnik (Eds.), Mending the World, Social Healing Interventions by Gestalt Practitioners worldwide, (2nd ed., pp. 64-92), Routledge, Taylor \& Francis Group.

Leary DeGruy, J. (2005). Post Traumatic Slave Syndrome: America's Legacy of Enduring Injury and Healing. Uptone Press. 
Mohatt, N. V., Thompson, A. B., Thai, N. D., \& Tebes, J. K. (2014). Historical trauma as public narrative: A conceptual review of how history impacts present-day health. Social Science \& Medicine, 106, 128-136. doi: 10.1016/j. socscimed.2014.01.043.

Noor, M., Vollhardt, J. R., Mari, S., \& Nadler, A. (2017). The social psychology of collective victimhood: Collective Victimhood. European Journal of Social Psychology, 47, 121-134. http://dx.doi.org/10.1002/ejsp.2300.

Palosaaria, E., Punamäkia, R., Qoutab, S., \& Diabc, M. (2013). Intergenerational effects of war trauma among Palestinian families mediated via psychological maltreatment. Child Abuse \& Neglect, 37(11), 955-968. https:// doi.org/10.1016/j.chiabu.2013.04.006.

Rosenthal, G. (Ed.) (2009). The Holocaust in Three-Generations. Families of Victims and Perpetrators of the Nazi-Regime. Opladen, Barbara.

Sagi-Schwartz, A., van IJzendoorn, M., \& Bakermans-kranenburg, M. (2008). Does intergenerational transmission of trauma skip a generation? No meta-analytic evidence for tertiary traumatization with third generation of Holocaust survivors. Attachment \& human development, 10, 105-21. 10.1080/14616730802113661.

Sangalang, C. C., \& Vang, C. (2017). Intergenerational Trauma in Refugee Families: A Systematic Review. Journal of Immigration and Minority Health, 19(3), 745-754. doi: 10.1007/s10903-016-0499-7.

Schori-Eyal, N., Klar, Y., Ben-Ami, Y. (2017a). Perpetual ingroup victimhood as a distorted lens: Effects on attribution and categorization. European Journal of Social Psychology, 47(2017), 180-194. https://docs.wixstatic.com/ ugd/75b8a6_994013fb9b2e42398ceec686c9f26eea.pdf

Schori-Eyal, N., Klar, Y., Roccas, S., \& McNeill, A. (2017b). The Shadows of the Past. Personality and Social Psychology Bulletin, 43(4), 538-554. https://doi. org/10.1177/0146167216689063

Spinazzola, J., Cook, A., Ford, J., Lanktree, C., Blaustein, M., Cloitre, M., DeRosa, R., Hubbard, R., Kagan, R., Liautaud, J., Mallah, K., Olafson, E., \& van der Kolk, B. (2005). Complex Trauma in Children and Adolescents. Psychiatric Annals, 35(5), 390-398. 10.3928/00485713-20050501-05.

Stamm, B. H., Stamm, H. E., Hudnall, A. C. \& Higson-Smith, C. (2004). Considering A Theory of Cultural Trauma and Loss. Journal of Loss and Trauma, 9(1), 89-111. DOI: 10.1080/15325020490255412.

Taylor, L., Štambuk, M., Corkalo Biruški, D., \& O’Driscoll, D. (2020). Transgenerational Transmission of Collective Victimhood Through a Developmental Intergroup Framework: The Lasting Power of Group Narratives of Suffering. In J. Vollhardt (Ed.), The Social Psychology of 
Collective Victimhood (pp. 37-55). Oxford University Press. 10.1093/ oso/9780190875190.003.0002.

Vollhardt, J. R. (2012). Collective victimization. In L. R. Tropp (Ed.), Oxford library of psychology, The Oxford handbook of intergroup conflict (pp. 136-157). Oxford University Press. https://www.academia.edu/4316854/Collective_ Victimization?auto=download.

Vollhardt, J. R., \& Bilali, R. (2014). The Role of Inclusive and Exclusive Victim Consciousness in Predicting Intergroup Attitudes: Findings from Rwanda, Burundi, and DRC. Political Psychology, 36(5), 489-506. https://doi. org/10.1111/pops.12174.

Volkan, V. (2001). Transgenerational Transmissions and Chosen Traumas: An Aspect of Large-Group Identity. Group Analysis, 34(1), 79-97. $10.1177 / 05333160122077730$.

Young, I. F., \& Sullivan, D. (2016). Competitive victimhood: a review of the theoretical and empirical literature. Current Opinion in Psychology, 11, 3034. https://doi.org/10.1016/j.copsyc.2016.04.004. 


\title{
TRANSGENERTIONAL VICTIMIZATION AND TRANSGENERTIONAL VICTIMHOOD: DEFINITIONS, MODES OF TRANSMISSION AND EFFECTS
}

\section{Maja Simonovska}

\begin{abstract}
The transmission of trauma from generation to generation is a phenomenon that is increasingly discussed the literature. There are several concepts in the literature that try to explain this phenomenon. The specificity of the transgenerational victimhood is reflected in the fact that the trauma is transmitted to the offspring who were not directly exposed to the traumatic event, and the effects are manifested not only on an individual but also on a group level. Scientific research is still in its infancy due to the complexity of this phenomenon and so far, the studies are mainly of a qualitative nature. The aim of this paper is to provide a basic overview of the concepts of transgenerational victimization and transgenerational victimhood, the way they are transmitted and their effects.
\end{abstract}

Keywords: transgenerational victimization, transgenerational victimhood, transmission, effects 